Review Article

\title{
Proterozoic Basins of Peninsular India: Status within the Global Proterozoic Systems
}

\author{
VIVEK S KALE* \\ Advanced Centre for Water Resources Development \& Management [ACWADAM], Sus Road, Pune 411 \\ 029, India \\ and \\ Department of Earth Sciences, Indian Institute of Technology (Bombay), Powai, Mumbai 411 076, India
}

(Received on 28 May 2016; Accepted on 10 June 2016)

\begin{abstract}
This compilation is intended to present a snap-shot of the current status of the knowledge on the Proterozoic sediments and tectonic events that are preserved in Peninsular India; on the backdrop of the growing understanding of global events and environmental evolution during that period. Proterozoic sediments in Peninsular India are found in two contrasting categories of basins. Narrow linear intercratonic belts host terrigenous and marine sediments, often interbedded with volcanics and volcaniclastics; that are deformed, metamorphosed and occasionally intruded by granitic bodies. These belts abut with a tectonic contact with wide, unmetamorphosed platform sediments from epicratonic basins with limited igneous activity associated within them; clubbed as the Purana Basins of Peninsular India. Although traditionally the former (mobile belts) were considered to be older and different from the latter, emerging geochronological data demonstrates that they were coeval products of basins evolving adjoining each other in diverse tectonic setting. Available knowledge on these basins is summarised within the framework of the emerging understanding of the Proterozoic geohistory punctuated by assembly and break-up of supercontinents, progressive oxygenation of the atmosphere, changes in the sea-water chemistry; establishment of the continental free-board and the generic environments that laid the foundation of biotic evolution. Although significant advances have been made in the last decade in the knowledge of these sediments, much more is required to achieve the desired precision and resolution.
\end{abstract}

Keywords: Proterozoic; Tectonics; Sedimentation; Peninsular India

\section{Introduction}

The Archean history of Peninsular India is recorded in the five distinct cratonic nuclei, namely Rajasthan, Bundelkhand, Bhandara (also named Bastar/Central Indian/Deccan by some authors), Singhbhum and Dharwar (Naqvi and Rogers, 1987; Sharma, 2009; Ramakrishnan and Vaidyanadhan, 2010; Meert et al., 2010; Valdiya, 2016). Constituted of a series of greenstone and high-grade metamorphic belts embedded in tonalite-throndhjemite gneissic complexes, their terminal Archaean accretion is marked by a major event of granitic activity that occurred around $2.5 \pm 0.1 \mathrm{Ga}$. The cratonisation of the Bhandara nucleus appears to have continued through the Paleoproterozoic time culminating with the
Dongargarh Granite and equivalents at around 2.2 \pm 0.1 Ga.

It is around these cratonic blocks of gneissic greenstone complexes that subsequent Proterozoic events have unfolded, with the cratons providing the source of terrigenous sediments to the basins that evolved around them in diverse tectonic settings. Fig. 1 depicts the geographic distribution of the various independently recognisable Proterozoic belts/basins in Peninsular India.

These Proterozoic sediments have been a subject of some exciting additions to our knowledge in the last couple of decades. Major changes have been effected in the conventional correlations between

*Author for Correspondence: E-mail: dr.vivekale@gmail.com 


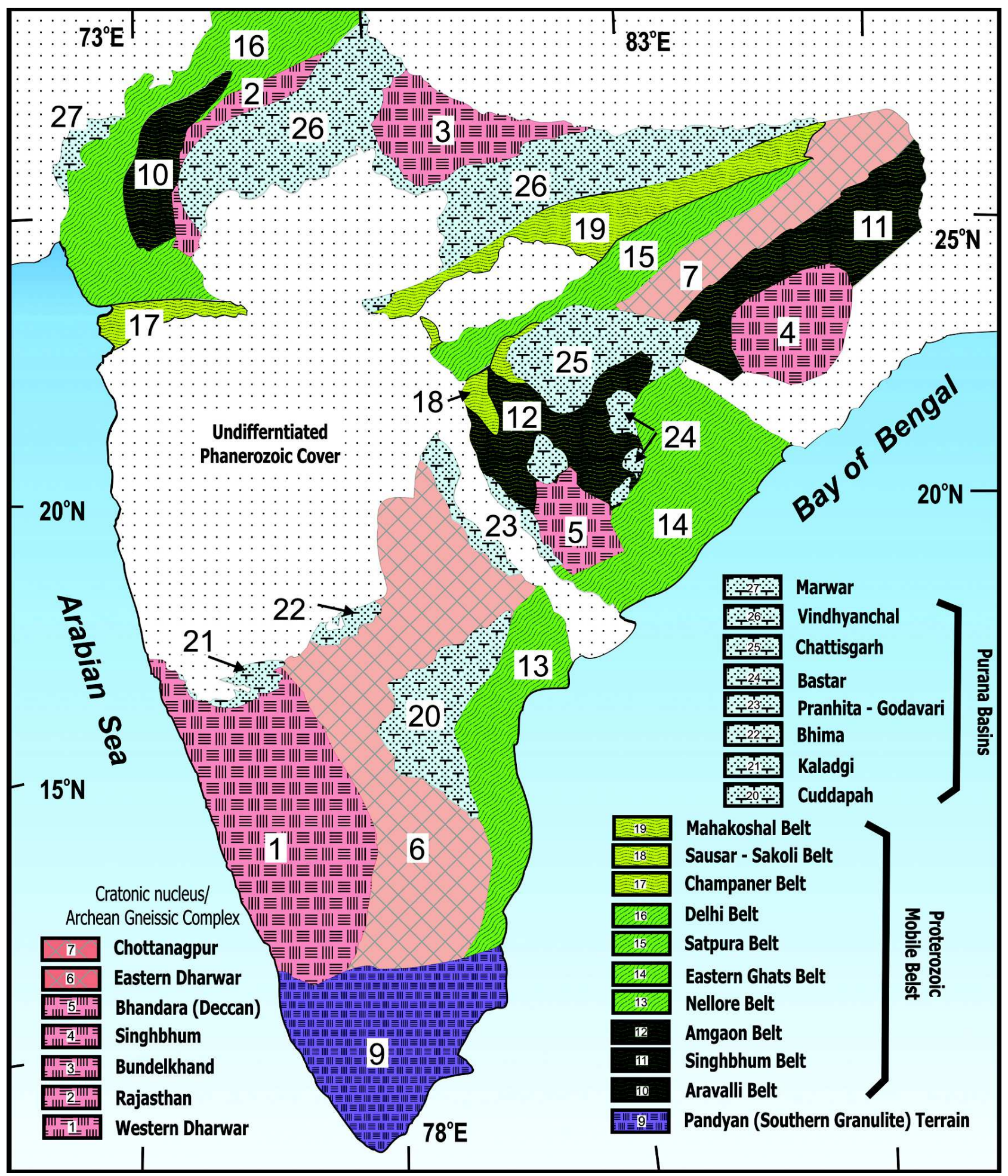

Fig. 1: Simplified map of the Precambrian terrains of Peninsular India (modified after Naqvi and Rogers, 1987; Sharma, 2009; with some updates (in nomenclature) from works cited in this paper. The cratonic nuclei and Archean Gneissic complexes listed on the left are dominantly constituted of TTG-Granite Greenstone terrains. The Proterozoic mobile belts (hosting metamorphosed and deformed suites) are depicted with darker shading for Paleoproterozoic belts and green shades for the Mesoproterozoic belts). The Marwar basin (earlier termed as 'Trans-Aravalli Vindhyans') is arguably the host of the youngest Proterozoic sediments (Neoproterozoic - Cambrian transition) in Peninsular India 
these sequences as a result of growing geochronological data. Sedimentological and structural studies have been supplemented by a series of biotic findings that have forced a reassessment of many established concepts. A greater appreciation of the basinal structure of these sedimentary suites has led to the recognition that traditional assumptions need to be replaced by modern concepts.

It would not be possible to discuss in depth the contributions made on each of them, but a precis of what is new to knowledge is enumerated here. Ramakrishnan and Vaidyanadhan (2010) provided a compilation of the state of the art for Indian Geology that was supplemented by the reviews of Meert et al. (2010), status reports of Bhowmik et al. (2012) and Chakraborty et al. (2012); followed by compilations in Sharma, Banerjee and Santosh-Eds (2014: Special Issue Journal of Asian Earth Sciences no: 91: Proterozoic Basins of India), Mazumder and Eriksson - Eds (2015: Geological Society London Memoir no. 43: Precambrian Basins of India stratigraphic and tectonic context) and Valdiya (2016). For sake of brevity (without diluting any credit from the individual contributors), the citations made in these compilations are not listed individually here unless specific points require.

\section{Age Data}

Modern precision geochronological methods have helped create a robust data-base that permits correlations across continental blocks, leading to major revisions in the traditional equivalences of stratigraphic units. The available age data on various Proterozoic sequences is compiled in Fig. 2. The sources of the ages/correlations used in compiling this are listed in the figure title. The available geochronology is at best capable of providing the broad age ranges in which the deposition occurred, often using indirect data eg: ages of intrusives in them or their basement (Pradhan et al., 2012; Kumar et al., 2015) or detrital zircon ages (Malone et al., 2008; Bickford et al., 2011; Amarsinghe et al., 2014; McKenzie et al., 2014; 2013; Basu and Bickford, 2015; Joy et al., 2015) to constraint the upper and lower ages of the component Groups from the various basins. Direct dating of the sediments and associated rocks (eg: Zachariah et al., 1999; Conrad et al., 2011; Gopalan et al., 2013; Tripathi and Singh, 2015) is sparse. The overall geochronological data lacks the resolution that would enable their precise inter-basinal correlation, akin to Phanerozoic correlations.

It is equally important to note that their preserved thicknesses suggest that a large majority of these sequences were deposited in time-spans of less than 10-20 million years, even if liberal estimates of subdued sedimentation rates are clubbed with very low preservation potential (see Kale and Phansalkar, 1991; Kale, 2015). The depositional environments of these sediments do not indicate muffled rates of accumulation if compared to modern analogues; barring exceptional horizons like black shales and glauconitic beds. Therefore while it is possible to bracket various 'Groups' as being within the same range of ages; it will be premature to consider them as being coeval (sensu stricto). These uncertainties are depicted in the chart by diagonal boundaries that also emphasis the possibility of their being timetransgressive.

\section{Biotic Contents}

These sequences have been reported to yield a diverse biotic record including stromatolitic assemblages, micro-organic remains, ichnofossils, casts and impressions of carbonaceous and other biotic forms.

Stromatolitic forms have been profusely reported from most of these Proterozoic sedimentary sequences, particularly those from the Purana basins. Till about 20 years back, stromatolite biostratigraphy (established in the Russian and Canadian Proterozoic platform deposits as well) appeared to have taken root in correlating these sequences and establishing a broad chronological framework. Over the years, this line of evidence appeared to yield diminishing returns and has now been almost abandoned in recent literature. The cyanobacterial material, carbonaceous bedding-plane markings, and microfossils reported from the stromatolitic strata is yielding significant information on the biotic remains preserved in these sedimentary sequences (Sergeev et al., 2012). Similarly, microbial mat-related structures are being recorded in wider areas across these sediments (eg: Sarkar et al., 2014) and there is a fair chance that some of the earlier interpreted dubio-structures may be explained by such mechanisms that accept the presence of microbial life but question the preservation of the body-form in the host sediments. 


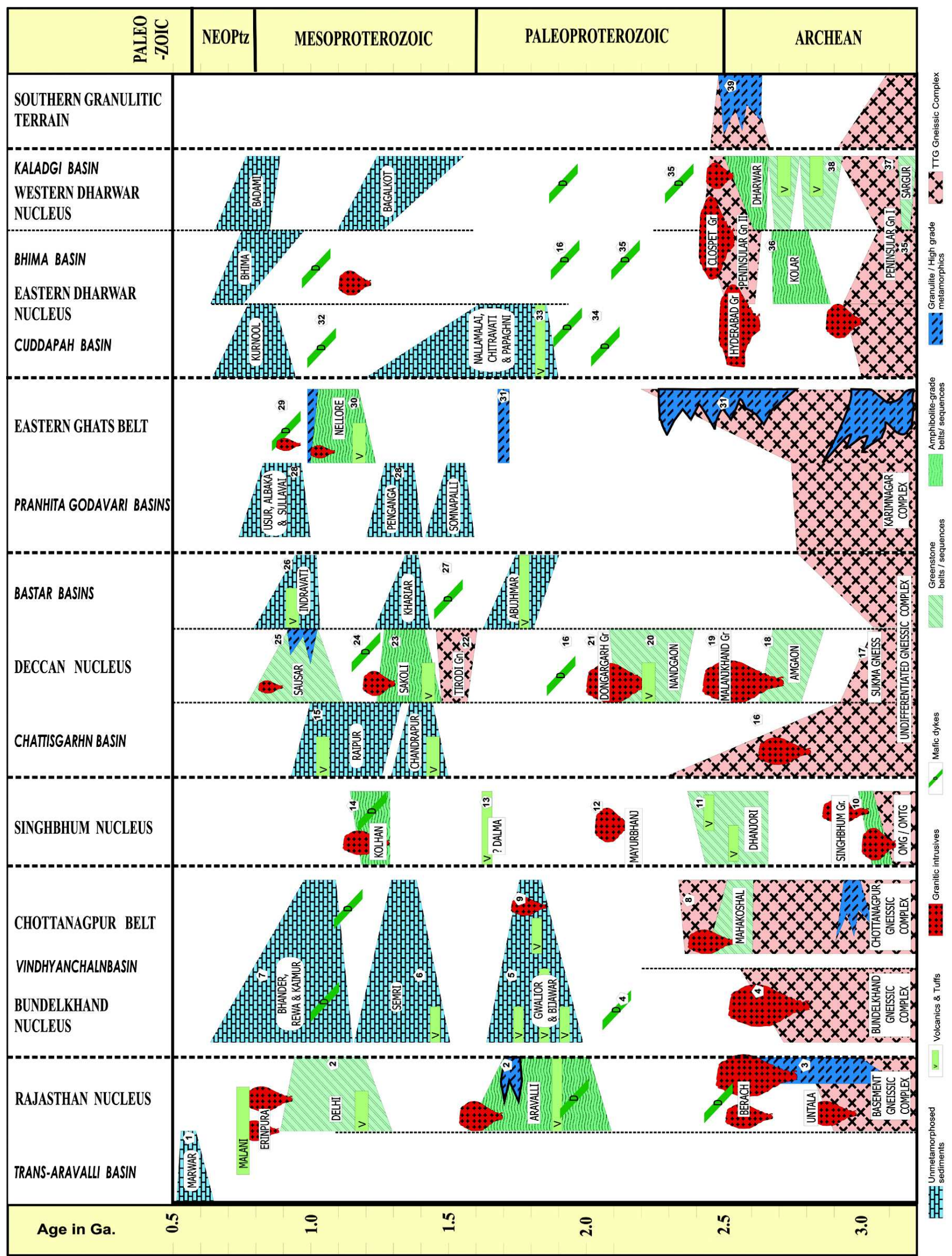

(Figure caption on page no. 465) 
There is a series of findings of ichnofossils, bedding plane markings and dubiofossils from the Vindhyanchal, Chattisgarh, Bhima, Kaladgi and Cuddapah basins (Kulkarni and Borkar, 2004). While such forms provide a better understanding of the depositional systems, they have failed to yield concrete pointers to the age of the host sediments. On the other hand, the controversial findings of small shelly fauna from the Vindhyans (Azmi et al., 2008; Bengtson et $a l ., 2009)$ have resulted in a reappraisal of the ageranges of some of these forms. The discovery of fossils of distinctive Cambrian affinities from the Marwar basin (Kumar and Pandey, 2008; Kumar, 2012; Sharma et al., 2014b and references therein) have demonstrated that these sediments (earlier termed as the Trans-Aravalli Vindhyans) need to be recognised separately and are the youngest of all Proterozoic sediments from Peninsular India.

The possibility of these sequences hosting a systematic record of biotic forms through the MesoNeo-Proterozoic is not too remote (Patranabis-Deb et al., 2007; Bengtson, 2009, Sharma et al., 2014a $\& b)$. However, these studies need to be tempered with caution and collaborated with isotopic (eg: Banerjee et al., 2006; Bhattacharya and Dutta, 2015; Patranabis-Deb et al., 2015) and sedimentological studies to ensure that such organic remains are methodically and unambiguously documented. They present the promise of hosting one of the best assemblages of the roots of the Phanerozoic biotic explosion.

\section{Unconformities}

As the geochronological data emerged in the last 20 30 years, it also became evident that the erstwhile "Great Eparchean Unconformity" that was presumed to separate the crystalline metamorphic rocks (of ?Archean age) and the unmetamorphosed sedimentary cover (equated with the Proterozoic) is not a tenable entity. Several metamorphic sequences are much younger than $2.5 \mathrm{Ga}$, putting them well inside the Proterozoic Eonthem. All the Proterozoic sequences in Peninsular India rest on the crystalline cratonic basement, separated by an unambiguous angular and erosional unconformity. This points to a protracted period of emergent erosion and weathering of the cratonic blocks. Notwithstanding its diversity in age (as is evident in Fig. 2) for various basins, this basal unconformity is established to have contributed to the evolution of significant placer deposits of diamonds and noble metals, notably in the Vindhyanchal, Chattisgarh, Bastar, Cuddapah and Kaladgi basins.

What has emerged in the last couple of decades is the association of this unconformity with radioactive mineralisation. Unconformity related uranium and thorium deposits are now recorded from the Kaladgi, Bhima, Cuddapah basins in particular by the Atomic Minerals Directorate of Exploration and Research (Singh et al., 1990; Dhana Raju et al., 2002; Kumar, et al., 2012b; Sridhar et al., 2014; Thomas et al., 2014). What appears to be a critical factor is the thermal rejuvenation of the basement by intrusion of either fertile granites or basic intrusives, followed by a phase of weathering that left behind a paleosol capable of hosting the enrichment of the radioactive minerals through epigenetic processes.

There is a strong case made out for assessing the paleosol horizons occurring atop the basement of these sequences. (eg: Och and Shields-Zhou, 2012; Mukhopadhyay et al., 2014) This could throw significant light on the continental regimes prior to the

Fig. 2: Ages of Proterozoic and Neoarchean sequences in the Indian Peninsula. Data compiled based on Kale (1995) with updated age data from (1) Sharma et al., 2014 b; (2) McKenzie et al., 2013, Meert et al., 2010 \& Roy and Purohit, 2015; (3) Sharma et al., 2014 a; (4) Mondal et al., 2002, Pradhan et al., 2012 (5) Chakraborty et al., 2015; (6) Rassmussen et al., 2002; Ray et al., 2002; (7) Gopalan et al., 2013; Tripathy and Singh, 2015; (8) Roy and Devarajan, 2000; (9) Dhurandhar et al., 2005; (10) Upadhyay et al., 2014; Meert and Pandit, 2015; (11) Roy et al., 2002a\&b; De et al., 2015, (12) Ramakrishnan and Vaidyanadhan, 2010, (13) Roy et al., 2002a; 2006 (14) Eriksson et al., 2006; Valdiya, 2016; (15) Das et al., 2009; Bickford et al., 2011; (16) French et al., 2008, Srivastava and Gautam, 2009; (17) Sarkar et al., 1990; (18) Sarkar et al., 1994; (19) Ghosh et al., 1996; (20 \& 21) Krishnamurthy, 1990, Sarkar et al., 1994; (22) Sarkar, 1994; (23) Bandopadhyay et al., 1990; (24) Ratre et al., 2010, Pisarevsky et al., 2012; (25) Roy et al., 2006; (26) Mukherjee et al., 2012 (27) Ratre et al., 2010; (28) Santosh et al., 2004; Amarsinghe et al., 2014; (29) Dharma Rao et al 2014; (30) Mezgar and Cosca, 1999; (31) Paul et al., 1990; (32) Valdiya, 2016; (33) Kumar et al., 2015; (34) Kumar et al., 2012a; (35) Srivastava et al., 2014; (36) Yang and Santosh, 2015; (37) Bidyananda et al., 2003; (38) Kumar et al., 1996, Ramakrishnan and Vaidyanadhan, 2010; (39) Clark et al., 2009 
transgressions that yielded the capping sediments. These paleosols and the basal conglomeratic beds in the sequences of different ages have the potential to yield critical data on the evolution of the climatic and weathering conditions through the Proterozoic for the Indian Peninsula.

Another interesting feature emerging from the compilation of the age data is the presence of an intrabasinal unconformity in all the sedimentary basins occurring around $1.1 \pm 0.2 \mathrm{Ga}$. This unconformity separates the younger and older sequences in the Vindhyanchal, Chattisgarh, Bastar, Pranhita- Godavari, Cuddapah and Kaladgi basins. The implications of this on the classification of the Purana sequences (into bipartite or tripartite) is a matter of separate discussion (eg. Basu and Bickford, 2015; Meert and Pandit, 2015). What is remarkable is that it corresponds to the age of metamorphism, often involving anatectic granite emplacements in the adjoining Mesoproterozoic mobile belts (eg. Delhi, SausarSakoli, Kolhan, Mahakoshal and Nellore).

\section{Sedimentary Contents}

The Proterozoic basins from Peninsular India exhibit an overwhelming dominance of quartzitic arenite (with subsidiary rudaceous components)- argillite carbonate associations that characterise 'passive extensional basins' occurring on the edge of continental blocks. Although the relative proportions of the individual components is variable in different constituent 'Groups' (Kale, 1991) they are absent by exception only. For example, the Rewa Group (from the Vindyanchal basin) is totally devoid of carbonate sedimentation.

These sediments are assigned to an array of supra-tidal, shore-face, inter-tidal and off-shore depositional systems, with occasional incidence of aeolian, evaporitic and euxinic environmental conditions. Some of the coarser detrital deposits are recognised to represent alluvial and off-shore (slopebreak) fans; while most are attributed to either deltaic or shore-face/coastal deposition. The argillaceous and carbonate deposits have been recognised generally to be associated with the mud-flat, shelf or lagoonal environment with some being ascribed to lacustrine origin.

The outstanding feature emerging from the review of the depositional environments deciphered for these sediments is their deposition in relatively shallow waters of less than $25 \mathrm{~m}$ depths (with maximum estimates of the deeper deposits being less than $100 \mathrm{~m}$ water columns).

Although sporadically recorded earlier, the occurrence of synsedimentary deformation in these sequences (eg: Kale et al., 1998; Patil Pillai and Kale, 2011) provides an insight into the fact that these sequences cannot be assigned to transgressive events alone, but that such marine incursions on the stabilised and eroded basements were aided by tectonically driven subsidence of the basin-floor. The presence of chert-breccias in several of the Proterozoic basins has also been interpreted to evidence synsedimentary tectonics (Kale and Patil Pillai, 2011).

The presence of associated basic volcanics is observed in the Mesoproterozoic sequences (Gwalior, Bijawar, Abujhmar, Papaghni) older than $1.5 \mathrm{Ga}$. The post 1.5 Ga sequences from mobile belts (eg: Delhi, Kolhan, Nellore) do however have interbedded magmatic rocks testifying to their evolution in collisional tectonic regimes. Other sequences younger than $1.0 \mathrm{Ga}$ are however characterised by a remarkable absence of associated igneous rocks (barring the tuffaceous horizons), suggesting that they were deposited on pericratonic platforms akin to extensional passive margins.

\section{Basinal Histories}

Traditional views interpreted many of these Proterozoic sequences (using the erstwhile correlations) as being the product of a series of marine incursions on the Indian shield at different times (e.g. Singh, 1980). Based on their contents, geometries and structural patterns, the Purana basins were recognised as independent epicratonic basins created in dominantly an extensional tectonic setting (Kale, 1991). It was also pointed out that their structural characters diagnostically demonstrate that they cannot be clubbed into a singular basin. Each of these sequences has a diverse subsidence history, geometry and contents. Nor does the age data support the assumption of unity.

That they are all 'supracrustal' (in the sense that they rest on crystalline continental crust) and none is an oceanic basin (using the classification of Allen 
et al., 2015) is attested to by their basement and basal unconformities separating them from older supracrustal rocks. The terrigenous origin of most of the constituent sediments from these Proterozoic basins is unambiguous. The diversity in their structural patterns and sedimentary -igneous contents indicates that the individual basins, perhaps initiated as extensional supracrustal, (?) pericratonic basins, that underwent changes in their characters in course of their evolution. Some (like the Aravalli, Delhi, Mahakoshal, Satpura and Nellore) eventually suffered compressive tectonism and metamorphism; yielding the mobile belts; while others ( Purana Basins) remained undeformed (except along some of their margins). The Bagalkot Group from the Kaladgi Basin may be considered as a 'incomplete fold belt' with strong axial folding (see Kale, 1991; Jayaprakash, 2007) that is analogous to folding encountered in the mobile belts, but lacks the degree of metamorphism suffered by them. Taken together, it is essential to point out that all the Proterozoic basins qualify as 'polyhistory' basins in context of the classifications of sedimentary basins, barring those (like the Bhima, Indravati) that are constituted of singular sequences. Miall et al. (2015) have refined the basinal classification of these basins based on modern concepts.

The association of the mobile belts adjoining them indicates that the tectonic histories of the Vindhyanchal (with the Aravalli - Delhi belt on the west and the Mahakoshal belt in the south), Bastar (with the Eastern Ghats on the east) and Cuddapah (with the Nellore belt on the east) were unquestionably tempered with the events of compressive (? collisional) tectonics occurring along their margins (eg: Collins et al., 2014). This aspect has implications on the global reconstructions of Proterozoic supercontinental assemblies.

\section{The Proterozoic Systems}

As against the traditional view of the Proterozoic being a 'gradual transitional period' between the hot, oxygendeficient, hyperactive Archean crustal and atmospheric regimes and the cooler, oxygenated and slower Phanerozoic regimes, the dramatic changes that happened during these 2000 million years of the "earth's middle ages" are nothing short of fascinating (see Cawood and Hawkesworth, 2014). The understanding of the Proterozoic environment and crustal history that has unfolded in the last 10-15 years has led to several significant modifications in earlier established concepts. A graphical summary of the key crustal and environmental characters as well as the tectonic features that are documented through the Proterozoic is given in Fig. 3.

The Proterozoic period shows that the crustal history is more episodic and punctuated with events than was earlier believed. Supercontinental assemblies and break-ups (based on paleomagnetic data that demonstrates proximity of cratonic blocks during specific time intervals and supported by tectonostratigraphic similarities in the constituent blocks) manifest these events on a global scale. Several contributions to the Proterozoic sequences of Peninsular India have attempted to establish their connection with these supercontinental cycles.

Distribution of zircon ages (Fig. 3A) have been used by several authors to identify such supercontinental cycles during the Proterozoic. The names of these assemblies have undergone changes in the last decade. Recent compilations of large datasets of a variety of geological events by Evans (2013), Condie and Kroner (2013), Cox and Hawkesworth (2014), Rooney et al. (2015), Condie et al. (2015, 2016) appear to conclude that the Proterozoic record is marked by Kenorland ( 2.7-2.4 Ga); Nuna (erstwhile Columbia: 1.8-1.5 Ga), Rodinia (1.1-0.9 Ga) and nascent Gondwana - Laurentia (starting around $0.7 \mathrm{Ga}$ ) supercontinental assemblies. Kenorland may have been preceded by 'Ur' $(\sim 3.0$ Ga) during the Archean. These analyses of the temporal distribution of various tectonic and environmental parameters through the Proterozoic (Fig. 3) show that:

- Number of cratons has reduced during the Archean - Proterozoic transition (Fig. 3B)

- The number of collisional orogens display distinctive peaks starting with the break-up of the existing supercontinents and reducing with the period of amalgamation and stability (Fig. 3C)

- Mantle temperatures (determined from the crystallisation of non-arc basalts) have reduced progressively through time (Fig. 3D)

- Passive margin abundance increases with time, 

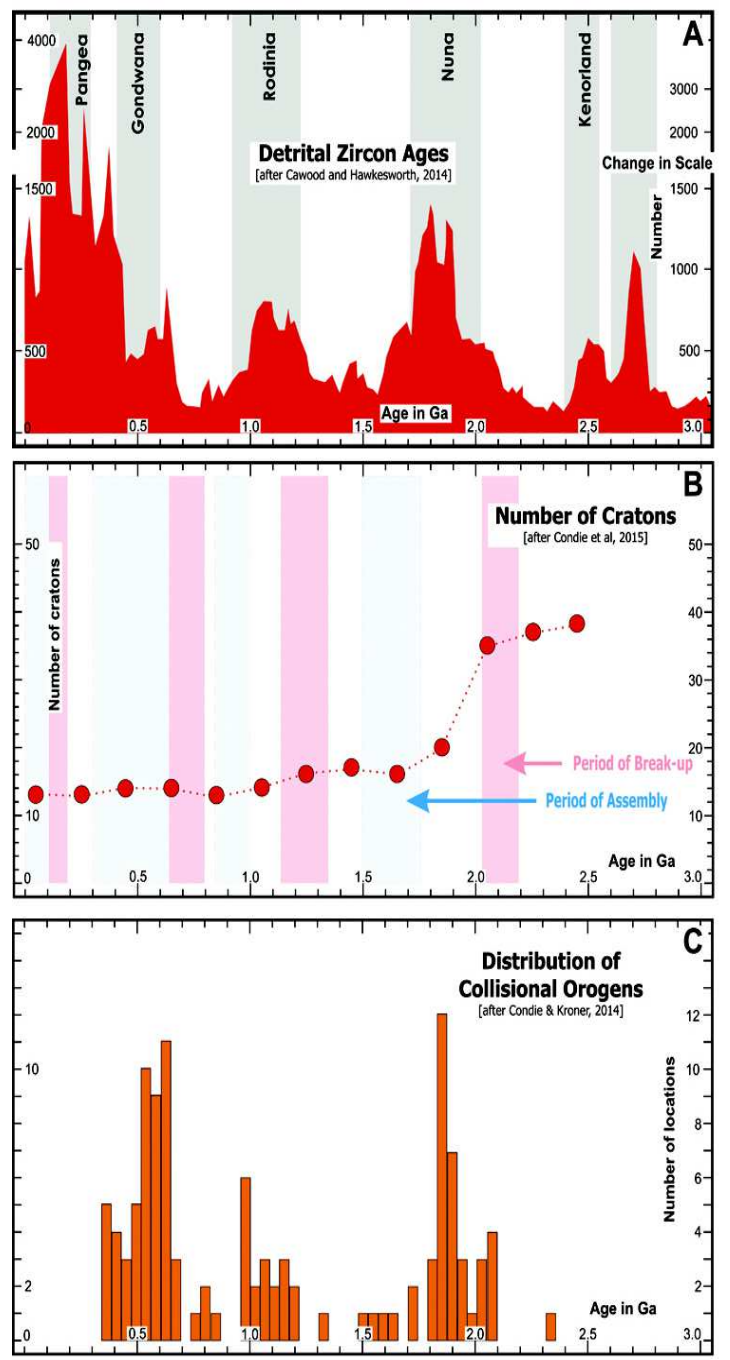
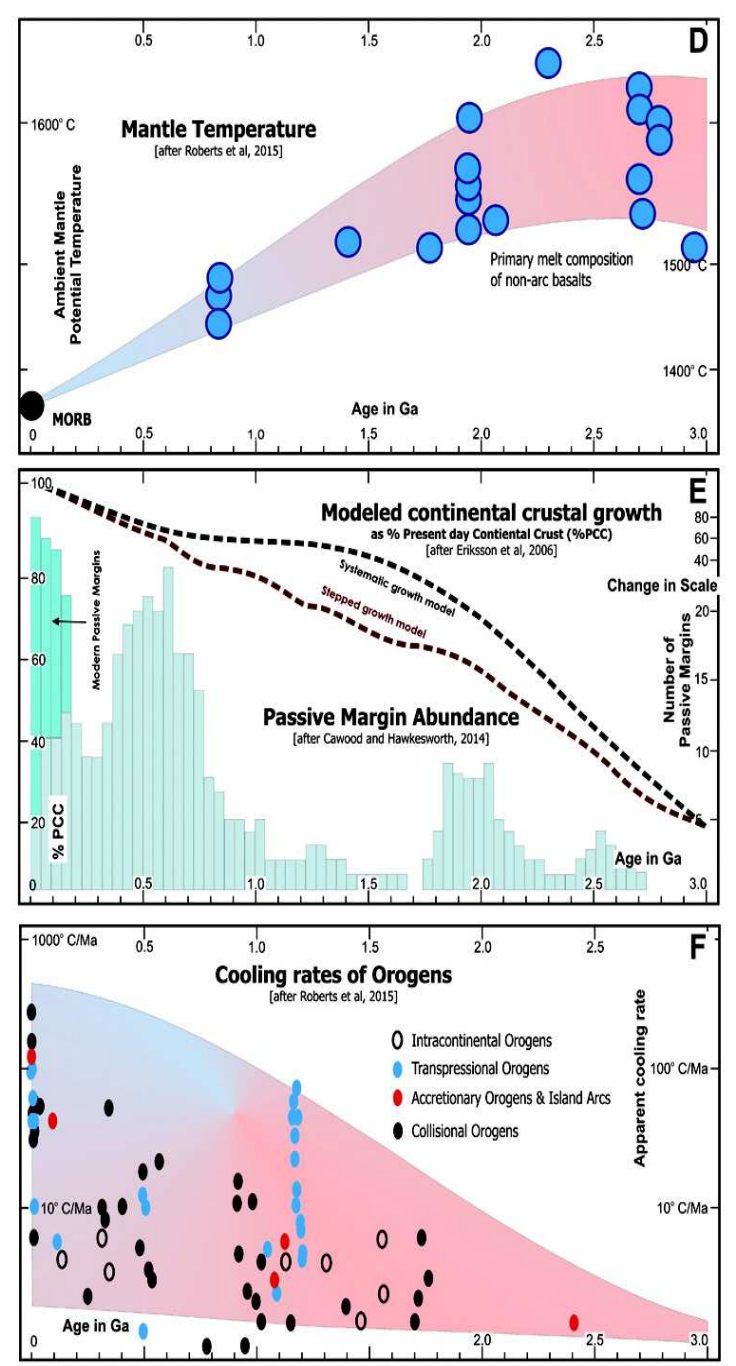
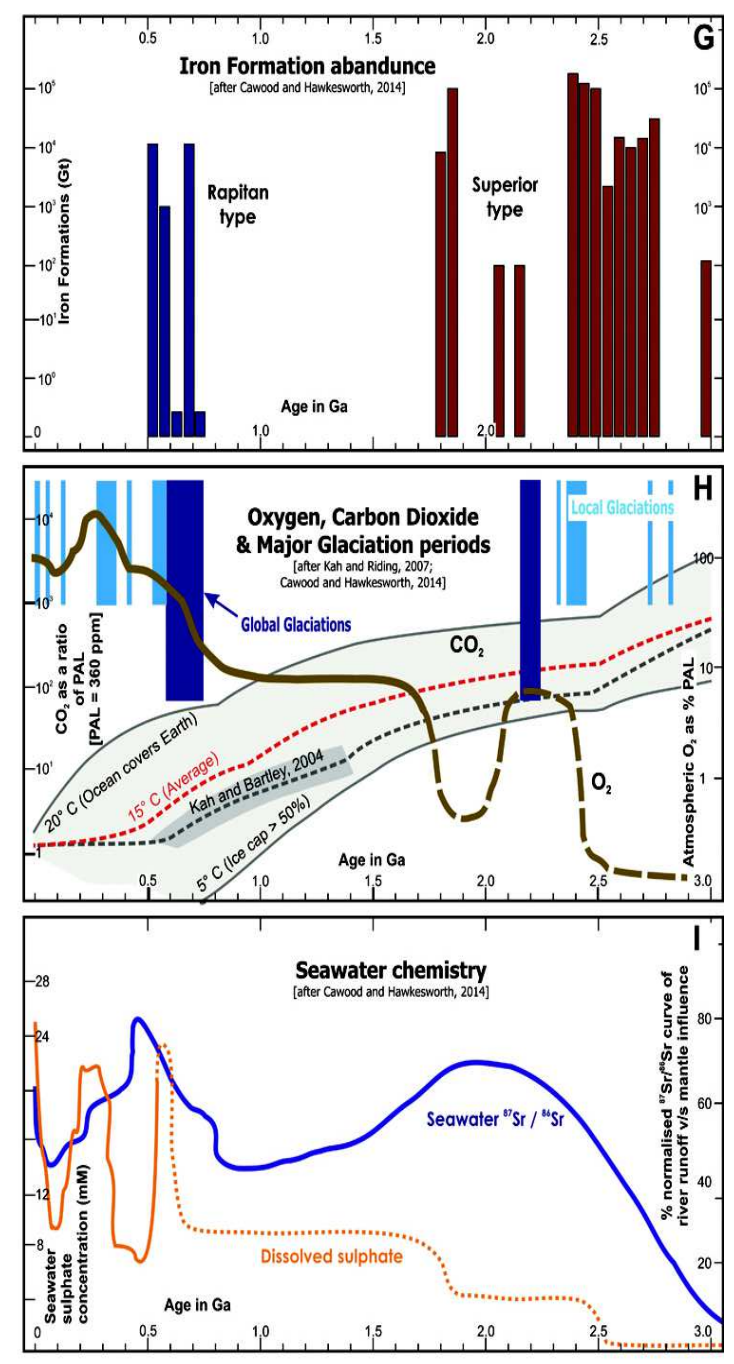

Fig. 3: Temporal distribution of Proterozoic environmental conditions and crustal features. Compiled from Kah and Riding, 2007; Evans, 2013; Cawood and Hawkesworth, 2014; Condie and Kroner, 2013; Rooney et al., 2015; Condie et al.; 2015, 2016 
but is punctuated by periods of supercontinental assemblies when there is an abrupt decrease in them (Fig. 3E).

All these features contribute to a revision in the assumption of a systematic (and progressively decelerating) growth of the continental crust through time. They indicate that it may be more appropriate to consider the possibility of an aperiodic stepped growth model (as shown in the 2 curves (modified after Eriksson et al., 2006 and Condie and Kroner, 2013) in Fig. 3E. The thicker and cooler continental crusts also have contributed to a slower cooling rate of compressive orogens over time, although it does not seem to have affected intracontinental and transpressional orogens (Fig. 3F). These crustal characters have obvious effects on the environments that existed during the Proterozoic.

During periods of supercontinental assembly, sea-levels are likely to be lower, with a dominance of continental climates promoting aridity and generally

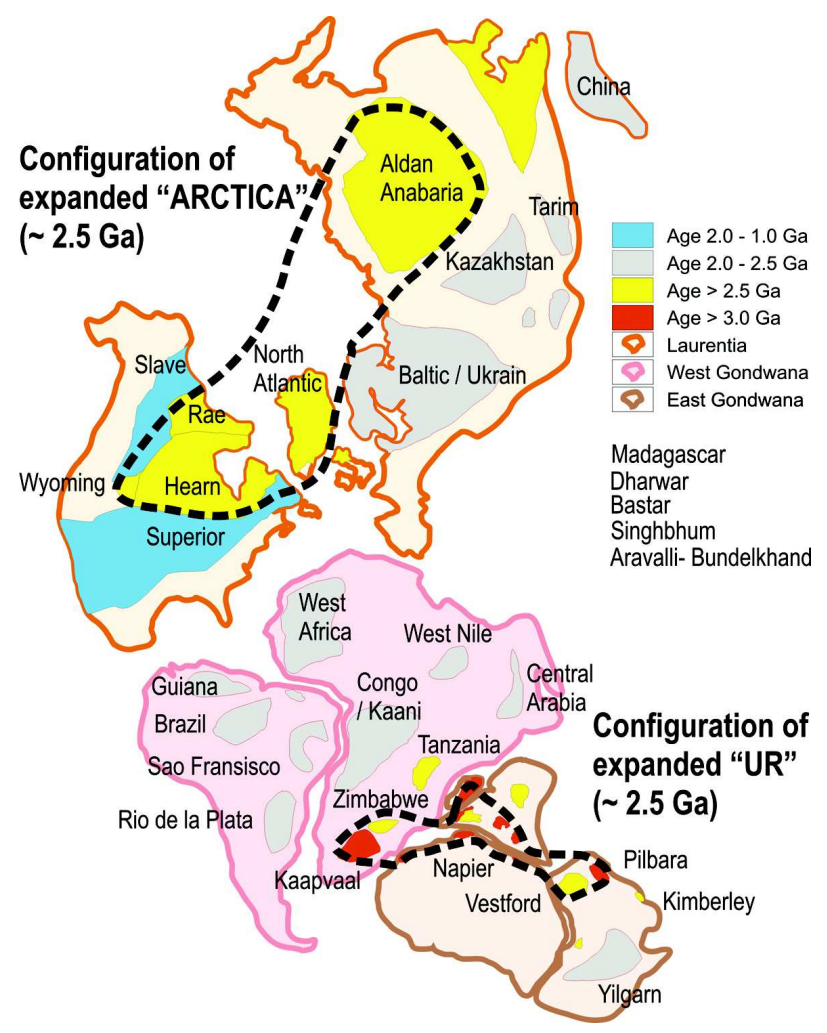

Fig. 4: (A) Projected configuration of supercontinent assemblies of UR and Arctica at the Archean Proterozoic boundary as compiled by Rogers and Santosh (2004). This assembly is now recognised as the Kenorland supercontinent

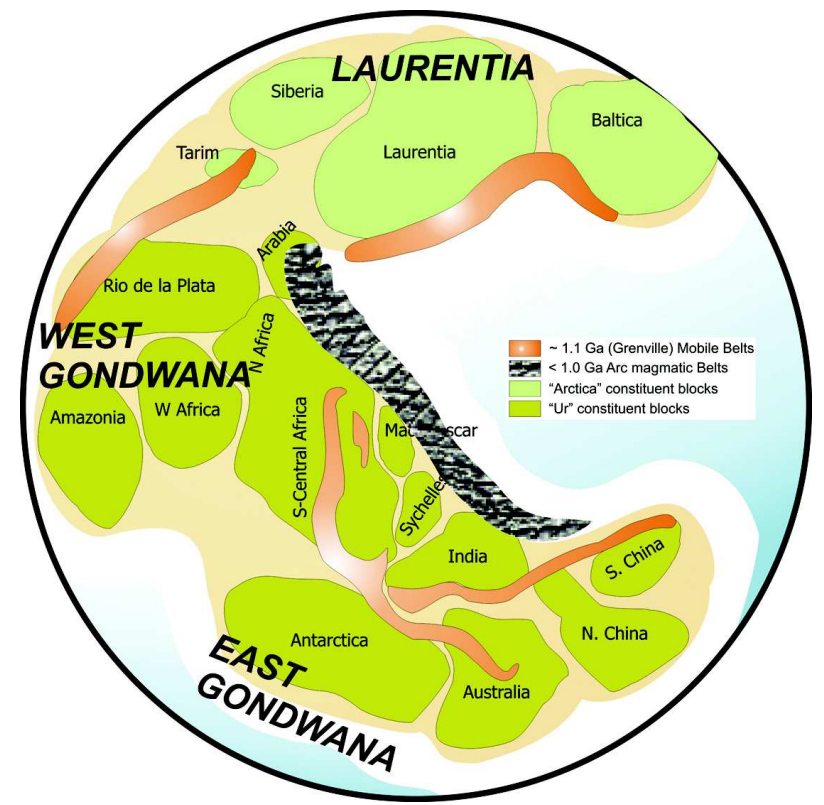

Fig. 4: (C) Assembly of continental blocks at around 1.0 Ga based on paleomagnetic data reconstructed by Piper (2013). The Mesoproterozoic supercontinental assembly is termed as Rodinia in recent literature. Note the 'overturning' of the Indian peninsular that is required for it to fit into the "Rodinia (eventually East Gondwana) assembly 
cooler environments that may lead to continental glaciations. On the other hand, dispersals promote higher sea-levels, increasing prevalence of wetter climates and higher temperatures (due to heat loss at spreading centres adding to existing solar insolation) leading to greenhouse-like environments. An added feature that results due to low gradients of the continental shelf systems is that small rises in sealevels will lead to larger flooded areas on the continents (Eriksson et al., 2006; Bradley, 2011). The available global records of volumes of iron formations (as a proxy of chemical weathering systems on continents) as well as glaciations (Fig. $3 \mathrm{G} \mathrm{\&} \mathrm{H}$ ) are consistent with these projections; but are characterised by a major gap of almost a billion years between $1.75 \mathrm{Ga}$ and $0.8 \mathrm{Ga}$. The correlation of the global glaciation in the Paleoproterozoic $(\sim 2.2 \mathrm{Ga})$ and the late Neoproterozoic (Sturtian [0.72-0.66 Ga] and Marinoan [ $0.63 \mathrm{Ga}]$ : Rooney et al., 2015) with Kenorland and Rodinia bears out this proposition rather strongly. The earlier assumption of progressive oxygenation of the atmosphere through the Proterozoic has also undergone significant revision, with the recognition of the 'great oxygenation event' (Och and ShieldsZhou, 2012; Lyons et al., 2014) that occurred during the Archean - Proterozoic transition (Fig. 3 H). There is now a far better understanding of the changes that occurred during the Proterozoic in the sea-water chemistry in terms of $\left({ }^{87} \mathrm{Sr} /{ }^{86} \mathrm{Sr}\right.$ ratios as a proxy of $)$ the volume of continental runoff contributions to primitive sea water, dissolved salts (or salinity) of the sea water (Fig. 3I) and the $\mathrm{CO}_{2}$ levels in the environment.

\section{Supercontinetal Assemblies}

Notwithstanding the fact that there have been attempts to correlate the events from the Indian subcontinent with global cycles (eg: Naqvi and Rogers, 1987; Meert et al., 2010; Basu and Bickford, 2015; Valdiya, 2016); Proterozoic paleomagnetic data and the paleo-positions of the Indian subcontinent have remained poorly studied. A sample of the 'fits' of the Indian peninsular block in projected assemblies of Kenorland $(\sim 2.5$ $\mathrm{Ga})$; Nuna $(2.0 \mathrm{Ga})$ and Rodinia $(1.0 \mathrm{Ga})$ is given in Fig. 4. Apparently, this block has undergone several twists and turns in its position during the Proterozoic. Kumar et al. (2012b), Radhakrishna et al. (2013) Belica et al. (2014: Fig. 16), and Pirajno and Santosh (2015: Fig. 15) have reinforced the fact that the peninsular block displays a very high mobility in terms of its pole-position deduced from paleomagnetic data. Was the Indian Peninsular block indeed so mobile, while other blocks display only a limited movement during equivalent periods of time? This requires a reappraisal to say the least.

All these assemblies assume that the entire peninsular shield of India was unified throughout the Proterozoic. The collisional tectonics recorded in the Aravalli - Delhi, Sausar - Sakoli, Dhanjori - Dalma Kolhan and Eastern Ghats - Nellore belts (earlier clubbed as the MPMB by Radhakrishna and Naqvi, 1986) suggest that this singularity may be open to debate. It is not unlikely that the smaller segments (=Rajashtan - Bundelkhand; Bhandara and Singhbhum) of the Peninsular India remained as independent nuclei separated from the Dharwar craton during the Paleoproterozoic times and assembled only during Mesoproterozoic times. Analogy is drawn from the emerging data and interpretations that demonstrate that smaller constituent blocks of African, Laurentian, Chinese shields were actually separated from each other and operated as independent nuclei until their assembly in Rodinia (Collins and Pisarevsky, 2005; Piper, 2013; Radhakrishna et al., 2013); while the entire Indian Peninsular continues to be shown as a single block.

A serious reassessment of this notion is not only desired, but also essential. A better justification of the accretionary tectonics (including its merger with the East Antarctic block) along the mobile belts during the Mesoproterozoic period leading to the development of 'Greater India' may emerge through this evaluation. The record of the unmetamorphosed sediments available in the adjoining Purana basins testify to a limited break-up of the accreted cratons, leading to elevated sea levels that flooded on the eroded continental crust.

\section{Concluding Remarks}

The Proterozoic record in the Indian Peninsula is an episodic one. It holds promise of hosting significant evidences of the contemporary atmospheric, oceanic, continental and biospheric systems. Bits and pieces of this have started to emerge and are yielding exciting and encouraging results. While fully appreciating the contributions that have been made to their knowledge in the last few decades (including numerous that 
remain uncited in this compilation for want of space) and the exponentially increasing data that is emerging, it remains short of the desired precision and unambiguous repeatability. The requirement is of a sustained, focussed and dedicated effort to look at these sequences in an integrated manner.

\section{Acknowledgements}

The patient encouragement of D M Banerjee is the primary driver of this compilation and I am enormously

\section{References}

Allen P A, Eriksson P G, Alkmim F F, Betts P G, Catuneanu O, Mazumder R, Meng Q and Young G M (2015) Precambrian basins of India: stratigraphic and tectonic context. In: Precambrian Basins of India: stratigraphic and tectonic context (Eds: Mazumder R and Eriksson P G) Geol Soc London Mem 43 5-28

Amarsinghe U, Chaudhuri A, Collins A S, Deb G and PatrabnisDeb S (2014) Evolving provenance in the Proterozoic Pranhita- Godavari baisn, India dyke swarm from south India: Constraints on Paleoproterozoic reconstruction Geosci Frontiers DOI: 10.1016/j.gsf.2014.03.009 12 p

Azmi R J, Joshi D, Tiwari B N, Joshi M N, Mohan K and Srivastava S S (2008) A synoptic view on the current discordant geo- and biochronological ages of the Vindhyan Supergroup, central India Him Geol 29 (2) 177-191

Bandyopadhyay B K, Bhaskar K G, Ramachandra H M, Khodse V K, Roy A, Mohan M, Sreeramchandra Rao K, Roy Burman T, Bishui P K and Gupta S N (1990) Recent geochronological studies in parts of the Precambrians of Central India Spl Pub Geol Surv India 28 199-210

Banerjee D M, Rastogi S P and Virender Kumar (2012) Someevaporite deposits of India Proc Indian Nat SciAcad 78 (3) 401-406

Banerjee S, Bhattacharya S K and Sarkar S (2006) Carbon and oxygen isotope compositions of the carbonate facies in the Vindhyan Supergroup, central India J Earth Sys Sci 115 113-134

Banerjee S, Dutta S, Paikary S and Mann U (2006) Stratigraphy, sedimentology and bulk organic geochemistry of black shales from the Proterozoic Vindhyan Supergroup (central India) J Earth Sys Sci 115 37-47

Basu A and Bickford M E (2014) Contributions of zircon U-Pb geochronology to understanding the volcanic and sedimentary history of some Purana basins, India J Asian grateful to him for the same. Ashok Singhvi is thanked for inviting this review and allowing some extra time for its submission. It is a pleasure to extend my gratitude to my peers A B Roy, R S Sharma, K S Valdiya for their sustained blessings and guidance; and to Rajat Mazumder, Sarbani Patranabis-Deb, Subir Sarkar and Mukund Sharma who very kindly flooded me with literature on the subject. This compilation would not have been possible without the efforts and support extended by Shilpa Patil Pillai.

\section{Earth Sci 91 252-262}

Basu A and Bickford M E (2015) An alternate perspective on the opening and closing of the Intracratonic Purana Basins in Peninsular India J Geol Soc India 85 5-25

Basu A, Patranabis-Deb S, Schieber J and Dhang P C (2008) Stratigraphic position of the $\sim 1000 \mathrm{Ma}$ Sukhda Tuff (Chattisgarh Supergroup, India) and the 500 Ma question Precamb Res 167 383-388

Belica M E, Pilspa E J, Meert J G, Pesonen L J, Plado J, Pandit M K, Kamenov G D and Celestino M (2014) Paleoproterozoic mafic dyke swarms from the Dharwar craton: paleomagnetic poles for India from 2.37 to $1.88 \mathrm{Ga}$ and rethinking the Columbia supercontinent Precamb Res 244 100-122

Bengtson S, Belivanova V, Rasmussen B and Whitehouse M (2009) The controversial "Cambrian" fossils of the Vindhyan are real but more than a billion years older Proc Nat Acad Sci DOI 10.1073 pnas.0812460106

Bhattacharjee I, Mukundhan A R, Sachan A S, Tiwary K N, Sinha R M and Gupta R K (2005) Proterozoic unconformity related uranium mineralisation around Chtiakhol, Korba district, Chattisgarh, India J Geol Soc India 65 619-623

Bhattacharya S and Dutta S (2015) Neoproterozoic - Early Cambrian biota and acient niche: A synthesis from molecular markers and palynomorphs from Bikaner - Nagaur Basin, western India Precamb Res 266 361-374

Bhowmik S K, Chattopadhyay A, Gupta S and Dasgupta S (2012) Proterozoic tectonics: an Indian perspective Proc Indian Nat Sci Acad 78 385-391

Bickford ME, Basu A, Patranabis-Deb S, Dhang PC and Scheiber J (2011) Depositional history of the Chattisgarh basin, central India: constraints from new SHRIMP zircon ages $J$ Geol 119 33-50

Bickford M E, Saha D, Schieber J, Kamenov G, Russell A and Basu A (2013) New U-Pb ages of zircons ini the Owk 
Shale (Kurnool Group) with reflections on Proterozoic porcellanites in India J Geol Soc India 82 207-216

Bidyananda M, Deomurari M P and Goswami J N (2003) ${ }^{207} \mathrm{~Pb}-$ ${ }^{206} \mathrm{~Pb}$ ages of zircons from the Nuggihalli schist belt, Dharwar craton, southern India Current Science 85 14821485

Bose P K, Sarkar S, Das N G, Banerjee S, Mandal A and Chakraborty N (2015) Proterozoic Vindhyan Basin: configuration and evolution. In: Precambrian basins of India: stratigraphic and tectonic context (Eds: Mazumder, R and Eriksson P G) Geol Soc London Mem 43 85-102

Bradley D C (2011) Secular trends in the geological record and supercontinental cycles Earth Sci Rev 108 16-33

Buchan K L (2013) Key paleomagnetic poles and their use in Proterozoic continent and supercontinent reconstructions: a review Precamb Res 238 93-110

Cawood P A, Wang Y, Xu Y and Zhao G (2013) Locating South China in Rodinia and Gondwana: a fragment of greater India lithosphere? Geology 41 903-906

Cawood P A and Hawkesworth C J (2014) Earth's middle age Geology 42 503-506

Chakraborty K and Roy A (2013) Petrogenesis of ultramafic mafic to felsic plutonic rock associations from souther portion of Chottanagpur Gneissic Complex in central India: A mutli-stage crust-mantle interaction process $J$ Geol Soc India 81 309-329

Chakraborty P P, Pant N C and Paul P P (2015) Controls on sedimentation in Indian Palaeoproterozoic basins - clues from the Gwalior and Bijawar basins, central India. In: Precambrian Basins of India: Stratigraphic and Tectonic Context (Eds: Mazumder R and Eriksson P G) Geol Soc London Mem 43 67-83

Chakraborty P P, Sarkar S and Patranabis-Deb S (2012) Tectonics and sedimentation of Proterozoic basins of Peninsular India Proc Indian Nat Sci Acad 78 393-400

Clark C, Collins A S, Timms N E, Kinny P D, Chetty T R K and Santosh M (2009) SHRIMP U-Pb age constraints on magmatism and high-grade metamorphism in the Salem Block, southern India Gond Res 16 27-36

Collins A S and Pisarevsky S A (2005) Amalgamating eastern Gondwana: the evolution of the circum-Indian orogens Earth Sci Rev 71 229-270

Collins A S, Patranabis-Deb S, Alexander E, Bertram C N, Falster G M, Gore R J, Mackintosh J, Dhang P C, Saha D, Pyne J L, Jourdan F, Backe G, Halverson G P and Wade B P (2014) Detrital mineral ages, radiogenic isotopic stratigraphy and tectonic significance of the Cuddapah basin, India Gond Res DOI: 10.1016/j.gr.2014.10.013

Condie K C and Kroner A(2013) The building blocks of continental crust: evidence for a major change in tectonic setting of continental growth at the end of the Archean Gond Res 23 394-402

Condie K C, Aster R C, Van Hunen J (2016) A great thermal divergence in the mantle beginning $2.5 \mathrm{Ga}$ : geochemical constraints from greenstone basalts and komatiites Geosci Frontiers DOI: 10.1016/j.gsf.2016.01.006

Condie K C, Davaille A, Aster R C and Arndt N (2014) Upstairs - downstairs: supercontinents and large igneous provinces, are they related? Int Geol Rev DOI: 10.1080/ 00206814.2014 .963170

Conrad J E, Hein J R, Chaudhuri A K, Patranabis-Deb S, Mukhopadhyay J, Deb G K and Beukes N J (2011) Constraints on the development of Proterozoic basins in central India from ${ }^{40} \mathrm{Ar} /{ }^{39} \mathrm{Ar}$ analysis of authigenic glauconitic material Bull Geol Soc America 123 158-167

Condie K C, Pisarevsky S A, Korenaga J and Gardoll S (2015) Is the rate of supercontinent assembly changing with time? Precamb Res 259 278-289

Crowe S A, Dossing L N, Beukes N J, Bau M, Kruger S J, Frei R and Canfield D E (2013) Atmospheric oxygenation three billion years ago Nature 501 535-538

Das K, Chakraborty P P, Hayasaka Y, Kayama M, Saha S and Kumura K (2015) c. 1450 Ma regional felsic volcanism at the fringe of the East India craton: constraints from geochronology and geochemistry of tuff beds from detached sediments basins. In: Precambrian Basins of India: Stratigraphic and tectonic context (Eds: Mazumdar R. and Eriksson PG) Geol Soc London Mem 43 207-221

Das N, Yokoyama K, Chakraborty P P and Sarkar A (2009) U$\mathrm{Th}-\mathrm{Pb}$ monazite dating and trace element geochemistry of tuff units from the basal part of the Chattisgarh and Khairiar basin, central India: implications for basin initiation and depositional contemporaneity J Geol 117 88-102

Dayal M, Mani D, Madhavi T, Kavitha S, Kalpana M S, Patil D J and Sharma M (2014) Organic geochemistry of the Vindhyan sediments: implications for hydrocarbons $J$ Asian Earth Sci DOI: 10.1016/j.jseaes.2014.03.010

De C (2006) Ediacaran fossil assemblage in the Upper Vindhyans of central India and its significance J Asian Earth Sci 27 660-683

De S, Mazumder R, Ohta T, Hegner E, Yamada K, Bhattacharyya T, Chiarenzelli J, Alterman W and Arima M (2015) Geochemical and Sm-Nd isotopic characters of the Late Archean - Paleoproterozoic Dhanjori and Chaibasa metasedimentary rocks, Singhbhum craton, E.India: 
implications for provenance and contemporary basin tectonics Precamb Res 256 62-78

De Kock M O, Beukes N J and Mukhopadhyay J (2015) Paleomagnetism of Mesoproterozoic limestone and shale successions of some Purana basins in southern India Geol Mag DOI: 10.1017/S0016756814000727

Deb M and Pal T (2015) Mineral potential of Proterozoic intracratonic basins in India. In: Precambrian basins of India: stratigraphic and tectonic context (Eds: Mazumder R. and Eriksson P G) Geol Soc London Mem 43 309-325

Dehler C M (2014) Advances in Neoproterozoic biostratigraphy spark new correlations and insight into evolution of life Geology 42 731-732

Dhana Raju R, Kumar M K, Babu E V S S K and Pandit S S (2002) Uranium mineralisation in the Neoproterozoic Bhima Basin at Gogi and near Ukinal: An ore petrological study J Geol Soc India 59 299-321

Dharma Rao C V, Santosh M and Zhangda S (2014) Neoproterozoic massif-type anorthosites and related magmatic suitesfrom the Eastern Ghats Belt, India: Implications for slab windowmagmatism at the terminal stage of collisional orogeny Precamb Res 240 60-78

Dhurandar A P, Latha A and Krishna V (2005) Geochronology and Petrochemsitry of the Dubha Granite, Sonbhadra district, Uttar Pradesh J Geol Soc India 65 459-467

Dobmeier C, Lutke S, Hammerschmidth K and Mezger K (2006) Emplacement and deformation of the Vinukonda metagranite (Eastern Ghats, India) - Implications for the geological evolution of peninsular India and for Rodinia reconstructions Precamb Res 146 165-178

Eriksson P G, Mazumder R. Catuneanu O, Bumby A J and Ilando B O (2006) Precambrian continental freeboard and geological evolution: a time perspective Earth Sci Reviews 79 165-204

Eriksson P G and Condie K C (2014) Cratonic sedimentation regimes in the ca. 2450-2000 Ma periods: Relationship to a possible widespread magmatic slowdown on Earth? Gond Res 25 30-47

Evans D AD (2013) Reconstructing pre-Pangean supercontinents Geol Soc America Bull 125 1735-1751

French J E, Heaman L M, Chacko T and Srivastava R K (2008) 1891-1883 Ma southern Bastar - Cuddapah mafic igneous event, India: A newly recognised large igneous province Precamb Res 160 308-322

Ghosh D K, Sarkar S N, Saha A K and Ray S L (1996) New insights on the early Archean crustal evolution in eastern India: Revaluation of $\mathrm{Pb}-\mathrm{Pb}, \mathrm{Sm}-\mathrm{Nd}$, and $\mathrm{Rb}-\mathrm{Sr}$ geochemistry Ind Min 50 175-188
Ghosh J G (2004) 3.56 Ga tonalite in the central part of the Bastar craton, India: oldest Indian date $J$ Asian Earth Sci 23 359-364

Gilleaudeau G J and Kah L C (2015) Heterogeneous redox conditions and a shallow chemocline in the Mesoproterozoic ocean: evidence from carbon - sulfur iron relationships Precamb Res 257 94-108

Goldberg A S (2010) Dyke swarms as indicators of major extensional events in the 1.9-1.2 Ga Columbia supercontinent $J$ Geodyn 50 176-190

Gopalan K, Kumar A, Kumar S and Vijaygopal B (2013) Depositional history of the upper Vindhyan succession, central India: time constraints from $\mathrm{Pb}-\mathrm{Pbisochron}$ ages of its carbonate components Precamb Res 233 108-117

Jayaprakash A V (2007) Purana Basins of Karnataka Mem Geol Surv India 129140

Joy S, Jelsma H, Tappe S and Armstrong R (2015) Shrimp U-Pb Zircon Provenance of the Sullavai Group of Pranhita Godavari Basin And Bairenkonda Quartzite of Cuddapah Basin With Impllications for the Southern Indian Proterozoic Tectonic Architecture J Asian Earth Sci 111 827-839

Kah L C and Riding R (2007) Mesoproterozoic cabron dioxide levels infrerred from calcified cyanobacteria Geology 35 799-802

Kale V S (1991) Constraints on the evolution of the Purana basins of Peninsular India J Geol Soc India 38 231-252

Kale V S (1995) Association of the Purana basins and the Middle Proterozoic Mobile belts in Peninsular India : Implications on targeting Uranium deposits Expl Res Atomic Min 8 95110

Kale V S (2015) Discussion on "An alternate perspective on the opening and closing of the Intracratonic Purana basins in Peninsular India” J Geol Soc India 85 627-631

Kale V S and Patil Pillai S (2011) A reinterpretaion of two Chertbreccias from, the Proterozoic basins of India J Geol Soc India 78 429-445

Kale V S and Phansalkar V G (1991) Purana Basins of Peninsular India: a review Basin Res 3 1-36

Kale V S, Nair S and Patil S (1998) Testimony of intraformational limestone breccias on Lokapur-Simikeri disconformity, Kaladgi Basin J GeolSoc India 51 43-48

Kamber B S (2015) The evolving nature of terrestrial crust from the Hadean, through the Archean, into the Proterozoic Precamb Res 258 48-82

Kemp D B and Sexton P F (2014) Time scale uncertainty of abrupt events in the geologic record arising from unsteady 
sedimentation Geology DOI: 10.1130/G35783

Krishnamurthy P (1990) Magmatic rocks of the DongargarhSupergroup, Central India - Their petrological evolution and implications on metallogeny Spl Publ Geol Surv India 28 303-309

Kulkarni K G and Borkar V D (2004) Scrutiny of the earliest records of biogenic sedimentary structures from the Proterozoic rock formations of the Indian shield $J$ Geol Soc India 62 222-226

Kumar A, Parasharumulu V and Nagaraju E (2015) A $2082 \mathrm{Ma}$ radiating dyke swarm in the Eastern Dharwar Craton, southern India and its implications to Cuddapah basin formation Precamb Res 266 490-505

Kumar A, Nagaraju E, Besse J and Bhaskara Rao Y J (2012a) New age, geochemical and paleomagnetic data on a 2.21 Ga dyke swarm from southern India: constraints on Paleoproterozoic reconstruction Precamb Res 220-221 123-138

Kumar A, Venkatesh A S, Ramesh Babu P V R and Nayak S (2012b) Genetic implications of rare uraninite and pyrite in quartz-pebble conglomerates from Sundargarh district of Orissa, eastern India J Geol Soc India 79 279-286

Kumar S (2012) Stratigraphy and correlation of the Neoproterozoic deposits of central and western India: an overview Sp Publ Geol Soc London 366 75-90

Kumar S and Pandey S K (2008) Arumberiabanksi and associated fossils from the Neoproterozoic Maihar Sandstone, Marwar Supergroup, Vindhyan Supergroup, central India J Palaeont Soc India $\mathbf{5 3}$ 83-97

Luo G, Ono S, Huang J, Algeo T J, Chao L, Zhao L, Robinson A, Lyons T W and Xie S (2015) Decline in oceanic sulfate levels during the early Mesoproterozoic Precamb Res 258 $36-47$

Lyons, T W, Reinhard C T and Planavsky N J (2014) The rise of oxygen in the Earth's early ocean and atmosphere Nature $506307-315$

Malone S J, Meert J G, Banerjee D M, Pandit M K, Tamrat E, Kamenov G D, Pradhan V R and Sohl L E (2008) Palaeomagnetism and detrital zircon geochronology of the Upper Vindhyan sequence, Son valley and Rajasthan, India: a ca 1000 Ma closure age for the Purana basins? Precamb Res 164 137-159

Martin A P, Condon D J, Prave A R and Lepland A (2013) A review of temporal constraints for the Paleoproterozoic large, positive carbonate carbon isotope excursion (the Lomagundi- Jatuli Event) Earth Sci Rev 127 242-261

Mazumder R and Eriksson P G (2015) Eds. Precambrian basins of India: stratigraphic and tectonic context Geol Soc London Mem 43352 p

Mckenzie N R, Hughes N C, Gill B C and Myrow P M (2014) Plate tectonic influence on Neoproterozoic - early Paleozoic climate and animal evolution Geology 42 127-130

Mckenzie N R, Hughes N C, Myrow P M, Banerjee D M, Deb M and Planavskye N J (2013) New age constraints for the Proterozoic Aravalli-Delhi successions of India and their implications Precamb Res 238 120-128

Meert J G and Pandit M K (2015) The Archean and Proterozoic history of Peninsular India: tectonic framework for Precambrian sedimentary basins in India. In: Precambrian basins of India: stratigraphic and tectonic context (Eds: Mazumder R. and Eriksson P G) Geol Soc London Mem $4329-54$

Meert J G, Pandit M K, Pradhan V R, Banks J, Sirianni R, Stroud M, Newstead B and Gifford J (2010) Precambrian crustal evolution of Peninsular India: a 3.0 billion year odyssey $J$ Asian Earth Sci 39 483-515

Mezger K and Cosca M A (1999) The thermal history of the Eastern Ghats Belt (India) asrevealed by U-Pb and ${ }^{40} \mathrm{Ar} /$

${ }^{39} \mathrm{Ar}$ dating of metamorphic and magmatic minerals: implications for the SWEAT correlation Precamb Res 94 251-271

Miall A D, Catuneanu O, Eriksson P G and Mazumder R (2015) A brief synthesis of Indian Precambrian basins: classification and genesis of basin-fills. In: Precambrian basins of India: stratigraphic and tectonic context (Eds: Mazumder R and Eriksson P G) Geol Soc London Mem 43 339-347

Mishra D C (2011) Long hiatus in Proterozoic sedimentation in India: Vindhyan, Cuddapah and Pakhal basins - a Plate tectonic model J Geol Soc India 77 17-25

Mishra D C and Ravi Kumar M (2013) Proterozoic orogenic belts and rifting of Indian cratons: Geophysical constraints Geosci Frontiers DOI: 10.1016/j.gsf.2013.03.003, 17 p

Mondal M E A, Goswami J N, Deomurari M P and Sharma K K (2002) Ion microprobe $207 \mathrm{~Pb} / 206 \mathrm{~Pb}$ ages of zircon from the Bundelkhand massif, northern India: implications for crustal evolution of the Bundelkhand - Aravalli protocontinent Precamb Res 117 85-110

Mukherjee A, Bickford M E, Hietpas J, Schieber J, and Basu A (2012) Implications of a newly dated ca. 1000 Ma rhyolitic tuff in the Indravati basin, Bastar craton, India J Geology 120 477-485

Mukhopadhyay J, Crowley Q G, Ghosh S, Ghosh G, Chakrabarti K, Misra B, Heron K and Bose S (2014) Oxygenation of 
the Archean atmosphere: new paleosol constraints from eastern India Geology DOI: 10.1130/G36091.1

Naqvi S M and Rogers J J W (1987) Precambrian Geology of India Oxford Monographs Geology \& Geophysics; Clarendon Oxford Press, Oxford 223p

Och LM and Shields-Zhou G A (2012) The Neoproterozoic oxygenation event: environmental perturbations and biogeochemical cycling Earth Sci Rev 110 26-57

Pandey U K, Bhattacharya D, Sastry D V L N and Pandey B K (2011) Geochronology ( $\mathrm{Rb}-\mathrm{Sr}, \mathrm{Sm}-\mathrm{Nd}$ and $\mathrm{Pb}-\mathrm{Pb}$ ), isotope geochemistry and evolution of granite and andesite hosting Mohar cauldron Expl Res Atomic Min 21 103-116

Pandey U K, Sastry D V L N, Pandey B K, Roy M, Rawat T P S, Ranjan R and Shrivastava V K (2012) Geochronology ( $\mathrm{Rb}-\mathrm{Sr}$ and $\mathrm{Sm}-\mathrm{Nd}$ ) stydies on intrusive gabbros and dolerite dykes from parts of Northern and Central Indian cratons: Implications for the age of onset of sedimentation in Bijawar and Chattisgarh basins and Uranium mineralisation $J$ Geol Soc India 79 30-40

Parihar P S (2013) Uranium and thorium resources in India: UNFC system www.unece.org/fileadmin/DAM/energy/se/pp/ unfc/UNFC_ws_India_Oct2013/5b.2_Parihar.pdf.

Parihar P S and Srinivasa Rao J (2012) Cuddapah Basin - an Uranium province Expl Res Atomic Min 22 1-5

Patil Pillai S and Kale V S (2011) Seismites in the Lokapur Subgroup of the Proterozoic Kaladgi Basin, south India: A testimony to syn-sedimentary tectonism Sed Geol $\mathbf{2 4 0} 1$ 12

Patra I, Chaturvedi A K, Srivastava P K and Ramayya M S (2013) Integrated interpretation of satellite imagery, aeromagnetic, aero-radiometric and ground exploration data sets to delineate favourable target zones for Unconformity related Uranium mineralization, Khariar Basin, central India J Geol Soc India 81 299-308

Patranabis-Deb S, Bickford M E, Hill B, Chaudhuri A K and Basu A (2007) SHRIMP ages of zircon in the uppermost tuff in Chattisgarh Basin in central Inda require $\sim 500 \mathrm{Ma}$ adjustment in Indian Proterozoic stratigraphy J Geology 115 407-415

Patranabis-Deb S, Schieber J and Chaudhuri A K (2007) Microbial mat features in mudstones of Mesoproterozoic Somanpalli Group, Pranhita-Godavari Basin, India. In: Atlas of microbial mat features preserved within the clastic rock record (Eds: Schieber J, Bose P K, Eriksson P G, Banerjee S, Sarkar S, Altermann W. and Catuneanu O). 171-180, Elsevier

Patranabis-Deb S, Slowakiewicz M, Tucker M E, Pancost R D and Bhattacharya P (2015) Carbonate rocks and related facies with vestiges of biomarkers: clues to redox conditions in the Mesoproterozoic ocean Gond Res DOI: 10.1016/ j.gr.2015.06.007, $15 \mathrm{p}$

Paul D K, Barman T, McNaughton N J, Flecther I R, Potts P J, Ramakrishnan M and Augustine P F (1990) ArcheanProterozoic evolution of Indian charnockites isotopes and geochemical evidence from granulites of the Eastern Ghat Belt $J$ Geology 98 253-263

Piper J D A (2013) A planetary perspective on Earth evolution: Lid tectonics before plate tectonics Tectonophysics 589 44-56

Pirajno F and Santosh M (2015) Mantle plumes supercontinents intracontinental rifting and mineral systems Precamb Res DOI: 10.1016/j.precamres.2014.12.016, $19 \mathrm{p}$

Pisarevsky S A, Biswal T K, Wang X C, Waele B D, Ernst R , Soderlund U, Tait J A, Ratre K, Singh Y K and Cleve M (2012) Paleomagnetic, geochronological and geochemical study of Mesoproterozoic Lakhna Dykes in the Bastar Craton, India: Implication for the Mesoproterozoic supercontinent Lithos doi:10.1016/j.lithos.2012.07.015

Pradhan V R, Meert J G, Pandit M K, Kamenov G and Mondal MEA(2012) Paleomagnetic and geochronological studies of the mafic dyke swarms of Bundelkhand craton, central India: implications for the tectonic evolution and paleogeographic reconstructions Precamb Res 198 57-76

Radhakrishna B P and Naqvi S M (1986) Precambrian continental crust of India and its evolution J Geology 94 145-166

Radhakrishna T, Krishnendu N R and Balasubramonian G (2013) Palaeoproterozoic Indian shield in the global continental assembly: evidence from the palaeomagnetism of mafic dyke swarms Earth Sci Rev 126 370-389

Ramakrishnan M and Vaidyanadhan R (2010) Geology of India (Volume 1) Geol Soc India Bangalore $1556 \mathrm{p}$

Rasmussen B, Bose P K, Sarkar S, Banerjee S, Fletcher I R and McNaughton I J (2002) 1.6 Ga U-Pbzirocon age for the Chorhat Sandstone, Lower Vindhyan: Possible implications for the early evolution of animals Geology 30 103-106

Ratre K, De Waele B, Biswal T K and Sinha S (2010) SHRIMP geochronology for the 1450 Ma Lakhna dyke swarm: its implications for the presence of Eoarchaean crust in the Bastar Craton and 1450-517 Ma depositional age for Purana basin (Khariar), Eastern Indian Peninsula J Asian Earth Sci 39 565-577

Ray J S, Martin M W, Veizer J and Bowring S A (2002) U-Pb zircon dating and $\mathrm{Sr}$ isotope systematics of the Vindhyan Supergroup, India Geology 30 131-134 
Retallack G J (2014) Volcanosedimentarypaleoenvironment of Ediacaran fossils in Newfoundland Geol Soc Am Bull 126 619-638

Ries J B, Fike D A, Pratt L M, Lyons T W and Grotzinger J P (2009) Superheavy pyrite $\left(\delta^{34} S_{\text {pyr }}>\delta^{34} S_{\text {CAS }}\right)$ in the terminal Proterozoic Nama Group, southern Namibia: as consequence of low seawater sulfate at the dawn of animal life Geology 37 743-746

Roberts N M W, Slagstad T and Viola G (2015) The structural, metamorphic and magmatic evolution of Mesoproterozoic orogens: Editorial Precamb Res 265 1-9

Rogers J J W and Santosh M (2004) Continents and Supercontinents Oxford Univ Press NY, 292 p

Rooney A D, Strauss J V, Brandon A D and Macdonald F A (2015) A Cryogenian chronology: two long-lasting synchronous Neoproterzoic glaciations Geology 43 459462

Roy A and Devrajan M K (2000) A reappraisal of the stratigraphy and tectonics of the Palaeoproterozoic Mahakoshal supracrustal belt, Central India. In: Proc. Int. Nat. Sem. Precambrian crust in Eastern and Central India, UNESCOIUGS-IGCP-368, Spl Publ Geol Surv India 57 79-97

Roy A, Kagami H, Yoshida M, Roy A, Bandyopadhyay B K, Chattopadhyay A, Khan A S, Huin A K and Pal T (2006) $\mathrm{Rb}-\mathrm{Sr}$ and Sm-Nd dating of different metamorphic events from the Sausar Belt, central India: Implications for Proterozoic crustal evolution J Asian Earth Sci 26 61-76

Roy A, Sarkar A, Jeyakumar S, Aggrawal S K and Ebihara M (2002a) Mid-Proterozoic plume related thermal event in eastern Indian craton: evidence from trace elements, REE geochemistry and $\mathrm{Sr}-\mathrm{Nd}$ isotope systematics of basicultrabasic intrusives from Dalma volcanic belt Gond Res 5 133-146

Roy A, Sarkar A, Jeyakumar S, Aggrawal S K and Ebihara M (2002b) Sm-Nd age and mantle characteristics of the Dhanjori volcanic rocks, Eastern India Geochem J 36503 518

Roy A B and Purohit R (2015) Lithostratigraphic, geochronological and depositional framework of the Precambrian basins of the Aravalli mountains and adjoining areas, Rajasthan, India. In: Precambrian basins of India: stratigraphic and tectonic context (Eds: Mazumder R and Eriksson P G) Geol Soc London Mem 43 55-65

Saha D and Mazumder R (2012) An overview of the Paleoproterozoic geology of Peninsular India, and key stratigraphic and tectonic issues Geol Soc London Spl Publ $3655-29$
Saha D and Tripathy V (2012) Tuff beds in Kurnool subbasin, southern India and implications for felsic volcanism in Proterozoic intracratonic basins Geosci Frontiers 3 429444

Santosh M, Yokoyama K and Acharyya S K (2004) Geochronolgy and tectonic evolution of Karimnagar and Bhopalpatnam granulite belts, central India Gond Res 7 501-518

Sarkar A, Sarkar G, Paul D K and Mitra N D (1990) Precambrian geochronology of the central Indian Shield - A review Spl Publ Geol Surv India 28 453-482

Sarkar G, Corfu F, Paul D K, McNaughton, N J, Gupta S N and Bishui P K (1993) Early Archean crust on Bastar craton, central India - a geochemical and isotopic study Precamb Res 62 127-137

Sarkar S, Banerjee S, Samanta P, Chakraborty N, Chakraborty P P, Mukhopadhyay S and Singh A K (2014) Microbial mat records in siliciclastic rocks: examples from four Indian Proterozoic basins and their modern equivalents in Gulf of Cambay J Asian Earth Sci 91 362-377

Sarkar S N, Sarkar S S and Ray S L (1994) Geochemistry and genesis of the Dongargarh Supergroup Precambrians of Bhandara-Durg, central India Indian J Earth Sci 21 117126

Sergeev V N, Sharma M and Shukla Y (2012) Proterozoic fossil cyanobacteria Paleobotanist 61 189-358

Sharma M and Shukla Y (2012) Megascopic carbonaceous compression fossils from the Neoproterozoic Bhima Basin, Karnataka, India. In: Geology and hydrocarbon potential of Neoproterozoic - Cambrian basins in Asia (Eds: Bhat G M, Craig J, Thurow J W, Thusu B and Cozzi A) Geol Soc London Spl Publ 366 277-293

Sharma M, Banerjee D M and Santosh M (2014a) Editorial: Proterozoic basins of Peninsular India J Asian Earth Sci 91 227-229

Sharma M, Pandey S K and Kumar S (2014b) International Field Workshop on the Marwar Supergroup, Rajasthan, IndiaField Guide The Society of Earth Scientists, Lucknow, 80 $\mathrm{p}$

Sharma R S (2009) Cratons and fold belts of India Springer Verlag, Berlin $304 \mathrm{p}$

Singh G, Banerjee D C, Dhana Raju R and Saraswat A C (1990) Uranium mineralization in the Proterozoic mobile belts of India Expl Res Atomic Min 3 83-101

Singh I B (1980) Precambrian sedimentary sequences in India: Their peculiarities and comparison with modern sediments Precamb Res 12 411-436

Sridhar M, Chaturvedi A K and Rai A K (2014) Locating new 
Uranium occurrences by integrated weighted analysis in Kaladgi basin, Karnataka J Geol Soc India 84 509-512

Srivastava R K and Gautam G C (2014) Geochemical characteristics and petrogenesis of four Palaeoproterozoic mafic dike swarms and associated igneous provinces from the eastern Dharwar craton, India Intern Geol Rev DOI 10.1080/00206814.2014.93836624 p

Srivastava R K, Samal A K and Gautam G C (2009) Precambrian maûc magmatism in the Bastar Craton, central India $J$ Geol Soc India 73 52-72

Thomas P K, Thomas T, Thomas J, Pandian M S, Banerjee R, Ramesh Babu P B, Gupta S and Vimal R (2014) Role of hydrothermal activity in uranium mineralization in Palnad Sub-basin, Cuddapah Basin, India J Asian Earth Sci DOI: 10.1016/j.jseaes.2014.02.013

Tripathy G R and Singh S K (2015) Re-Os depositional age for black shales from the Kaimur Group, Upper Vindhyan, India Chem Geol 413 63-72

Upadhyay D (2008) Alkaline magmatism along the southeastern margin of the Indian shield: Implications for regional geodynamics and constraints on craton - Eastern Ghats Belt suturing Precamb Res 162 59-69

Upadhyay D, Chattopadhyay S, Kooijman E, Mezger K and Berndt J (2014) Magmatic and metamorphic history of Paleoarchean tonalite-trondhjemite-granodiorite (TTG) suite from the Singhbhum craton, eastern India Precamb Res 252 180-190
Valdiya K S (2016) The making of India - Geodynamic Evolution. Springer International Switzerland, $924 \mathrm{p}$

Verma A and Shukla U K (2015) Deposition of the Upper Rewa Sandstone Formation of Proterozoic Rewa Group of the Vindhyan Basin, M.P.: A reappraisal J Geol Soc India 86 421-437

Yang Q-Y and Santosh M (2015) Zircon U-Pb geochronology and $\mathrm{Lu}-\mathrm{Hf}$ isotopes from the Kolar greenstone belt, Dharwar Craton, India: Implications for crustal evolution in an ocean-trench-continent transect $J$ Asian Earth Scis 113 797-811

Yedekar D B, Jain S C and Nair K K K (1990) The Central Indian collision suture. In: Precambrian of Central India Geol Surv India Spl Publ 28 1-27

Zachariah J K, Bhaskar Rao Y J, Srinivasan R and Gopalan K (1999) $\mathrm{Pb}, \mathrm{Sr}$ and $\mathrm{Nd}$ isotope systematics of Uranium mineralised stromatolitic delomites from the Proterozoic Cuddapah Supergroup, South India: Constraints on age and Provenance Chem Geol 162 49-64

Zao G, Sun M, Wilde S A and Li S Z (2004) A PaleoMesoproterozoic supecontinent assembly, growth and breakup Earth Sci Rev 67 91-123. 